\title{
IAMJ
}

INTERNATIONAL

AYURVEDIC

MEDICAL JOURNAL

\section{REVIEW OF PUNNARNAVA GUGGULU IN THE MANAGEMENT OF AMAVATA - RHEUMATOID ARTHRITIS w.s.r. BHAISHAJYA RATHNAVALI}

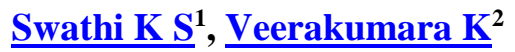 \\ ${ }^{1}$ PG Scholar, ${ }^{2}$ Associate Professor \\ Department of PG studies in Kayachikitsa, Sri Dharmasthala Manjunatheswara College of Ayurveda and \\ Hospital, Kuthpady, Udupi-574118, Karnataka, India
}

Corresponding Author: swathiksathyendran@gmail.com

https://doi.org/10.46607/iamj3109122021

(Published Online: December 2021)

Open Access

(C) International Ayurvedic Medical Journal, India

Article Received: 30/11//2021 - Peer Reviewed: 01/12/2021 - Accepted for Publication 02/12/2021

\section{Check for updates}

\begin{abstract}
Introduction: Rheumatoid arthritis (RA) is the most common variety of inflammatory arthritis. The annual incidence of RA worldwide is approximately estimated to be 3 cases per 10,000 populations. Based on the similar signs and symptoms RA can be compared with Amavata. It is not described in Brihatrayi as a separate disease the first detailed description was given by Acharya Madhavakar. The available contemporary treatment modalities are not satisfactory therefore Ayurvedic medicines are needed of the hour. Bhaishajya Rathnavali has been mentioned Punnarnava Guggulu in the management of Amavata. Aim: To critically study the mode of action of Punnarnava Guggulu in the management of Amavata w.s.r. Bhaishajya Rathnavali. Methods: For this study Ayurveda Samhita-Madhava Nidana, Authentic publications and modern literature have been reviewed. Conclusion: The Punnarnava Guggulu is Shothahara, Vedanasthapaka, Vatahara, Agnivardhaka and Amapachaka. So, it is concluded that Punnarnava Guggulu can be used as an effective medicine for Amavata.
\end{abstract}

Keywords: Punnarnava Guggulu, Amavata, Rheumatoid arthritis 


\section{INTRODUCTION}

Rheumatoid arthritis (RA) is the most common variety of chronic inflammatory arthritis marked by symmetric, peripheral polyarthritis. It often results in joint damage and physical disability. As it is a systemic disease, Rheumatoid arthritis may result in a variety of extra-articular manifestations, including fatigue, subcutaneous nodules, lung involvement, pericarditis, peripheral neuropathy, vasculitis, and haematological abnormalities. ${ }^{1}$ Worldwide, the annual incidence of RA is approximately 3 cases per 10,000 populations, and the prevalence rate is approximately $1 \% .^{2}$ Based on similar symptoms Rheumatoid arthritis can be compared with Amavata.

In the Brihatrayi Amavata is not described as a separate disease. The first detailed description of Amavata is available in Madhava Nidana. Viruddhahara Cheshta (Incompatible foods and habits), Mandhagni (decreased agni), Nishchalata (sedentary lifestyle), and doing exercise immediately after taking Snigdha
Ahara are the main causative factors of the disease Amavata. Angamarda (myalgia), Aruchi (anorexia), Trishna (thirst), Alasya (laziness), Gourava (heaviness), Jwara(fever), Apaka (indigestion), Angashunata (swelling) are the signs and symptoms of Amavata. ${ }^{3}$ The available contemporary treatment modalities are not satisfactory for the management of Rheumatoid arthritis. In this review paper, a holistic approach is made to evaluate the mode of action of Punnarnava Guggulu in the management of Amavata - rheumatoid arthritis.

\section{AIM AND OBJECTIVES}

To critically study the mode of action of Punnarnava Guggulu in the management of Amavata - Rheumatoid arthritis as per Bhaishajya Rathnavali.

\section{MATERIALS AND METHODS}

For this study Ayurveda Samhita - Madhava Nidana, Authentic publications and modern literature have been reviewed.

\section{DRUG REVIEW}

Table 1: Ingredients and Rasapanchaka Of Punnarnava Guggulu ${ }^{4}$

\begin{tabular}{|c|c|c|c|c|c|c|}
\hline $\begin{array}{l}\text { S. } \\
\text { No. }\end{array}$ & Drug & Guna (Properties) & Rasa (Taste) & $\begin{array}{l}\text { Vipaka (Taste } \\
\text { conversion after } \\
\text { digestion) }\end{array}$ & $\begin{array}{l}\text { Virya (Po- } \\
\text { tency) }\end{array}$ & Dosha Karma \\
\hline 1 & $\begin{array}{l}\text { Punnarnava } \\
\text { (Boerhavia dif- } \\
\text { fusa) }\end{array}$ & Sheeta, Laghu & Tikta & Katu & Sheeta & $\begin{array}{l}\text { Kaphapittahara } \\
\text { Shodhahara }\end{array}$ \\
\hline 2 & $\begin{array}{l}\text { Eranda moola } \\
\text { (Ricinus com- } \\
\text { munis) }\end{array}$ & Guru & Madhura & Madhura & Ushna & $\begin{array}{l}\text { Vatahara } \\
\text { Angamarda prasha- } \\
\text { mana }\end{array}$ \\
\hline 3 & $\begin{array}{l}\text { Shunti } \\
\text { (Zingiber offici- } \\
\text { nale) }\end{array}$ & Laghu, Snigdha & Katu & Madhura & Ushna & $\begin{array}{l}\text { Kaphavatahara } \\
\text { Pachana }\end{array}$ \\
\hline 4 & $\begin{array}{l}\text { Shuddha Guggu- } \\
\text { lu } \\
\text { (Commiphora } \\
\text { mukul) }\end{array}$ & $\begin{array}{l}\text { Vishada, Ruksha, } \\
\text { Laghu, Sukshma, } \\
\text { Pichila }\end{array}$ & $\begin{array}{l}\text { Tikta, } \\
\text { Kashaya, } \\
\text { Katu }\end{array}$ & Katu & Ushna & $\begin{array}{l}\text { Tridoshahara } \\
\text { Balya } \\
\text { Vedanasthapaka }\end{array}$ \\
\hline 5 & $\begin{array}{l}\text { Eranda taila } \\
\text { (Ricinus com- } \\
\text { munis) }\end{array}$ & $\begin{array}{l}\text { Theekshna, } \\
\text { Sukshma, Pichila, } \\
\text { Guru, Sara }\end{array}$ & Madhura, Kashaya & Madhura & Ushna & $\begin{array}{l}\text { Vatakaphahara, } \\
\text { Srotovishodhana }\end{array}$ \\
\hline 6 & $\begin{array}{l}\text { Trivrit } \\
\text { (Operculina tur- } \\
\text { pethum) }\end{array}$ & Ruksha & Madhura & Katu & Ushna & $\begin{array}{l}\text { Vatanashaka, } \\
\text { Virechaka }\end{array}$ \\
\hline 7 & Danthi moola & Sara, Teekshna & Madhura & Katu & Ushna & Pittakaphahara, \\
\hline
\end{tabular}






\section{METHOD OF PREPARATION} $>$ GUGGULU SHODHANA

- Raw Guggulu is taken, before doing Shodhana impurities like stone, bark, glass etc. were manually removed.

- Then using Khalwa Yantra Guggulu is pounded into small pieces.
- The Guggulu is then bundled in a twofold clean cloth and made a Pottali out of it and subjected to Dolayantra Swedana in Godugdha four times.

- Boiling is continued until all the Guggulu trickles into the Godugdha through the cloth and is collected at the bottom of Dolayantra. The residue in the cloth with physical impurities is discarded. 
- After the milk turns cools the Guggulu settled at the bottom is collected then it is dried in place of free from dust and kept in a glass jar free from moisture

- This Shuddha Guggulu can be used for the preparation of Punnarnava Guggulu.

> SWARNA MAKSHIKA SHODHANA

- The pieces of Swarna Makshika are taken in a clean Khalwa Yantra and pounded into fine powder form.

- This powder is taken in a clean iron vessel and added with enough quantity of Kadali Kanda Swarasa.

- Then the vessel was placed over an intense fire and cooked for one hour with frequent stirring.

- Later, the obtained dry powder (Shuddha Swarna Makshika) is stored in an airtight container.

$>$ BHALLATAKA SHODHANA ${ }^{6}$

- Bhallathaka is made into pottali and subjected to Dolayantra Swedana with Narikelambu for one Yama.

$>$ PREPARATION OF PUNNARNAVA GUG$\boldsymbol{G} \boldsymbol{U} \boldsymbol{L} \boldsymbol{U}^{7}$

Preparation of Punnarnava Guggulu is mentioned in the Bhaishajya Rathnavali.

- Prepare the Sukshma Churna of all specified ingredients and keep it aside.

- Then prepare Kwatha using a prescribed quantity of Punnarnava (100 Pala), Eranda moola (100 Pala), Shunti (16 Pala) and Jala (2 Drona) and reduced to $1 / 8^{\text {th }}$ of liquid.

- $\quad$ To the filtered Kwatha, Shudha Guggulu (8 Pala) is added and the boiling is continued till the mixture becomes a thick consistency.

- Then Eranda taila (1 Kudava) and fine powder of Trivrit (5 Pala), Danti moola (1 Pala), Guduchi (2 Pala) Triphala (1/2 Pala each), Trikatu (1/2 Pala each), Chitraka (1/2 Pala), Saindhava (1 Pala), Shuddha Bhallataka (1 Pala), Vidanga (1 Pala), Swarna Makshika (1 Karsha), Punnarnava (1 Pala) are added and mixed homogeneously.
- Then prepare Gutika of Mashatraya pramana and dry them under shade and preserve them in an airtight container.

DOSE-3 Masha

INDICATIONS

$>$ Amavata

$>$ Vataraktha

$>$ Vridhi roga

$>$ Grdrasi

\section{DISCUSSION}

Ama Dosha and vitiated Vata Dosha are the main causative factor in the pathogenesis of Amavata. Each and every ingredient in the Punnarnava Guggulu alleviates Ama and Vata Dosha in the body.

Punnarnava is beneficial to treat a wide range of diseases. Punnarnava have Shothahara property it is mainly used to alleviate pain and swelling. It is the most commonly used and the best herb to alleviate swelling due to its potent diuretic property.

The roots of Eranda are used in the treatment of Amavata, Sotha, Katisula etc. Its roots have also been highlighted for its Vatahara actions by Acharya Charaka and also possess laxative and antiinflammatory activities. Eranda Taila also acts as a laxative, and it also relieves Vata and Kapha Dosha. Guggulu has properties like Vata Nashaka and Vedanasthapaka (analgesic action). It contains essential oil consisting of myrcene, dimyrecene, polymyrecene, z-guggulusterone, E-guggulusterone. These isolates have been found useful in treating diseases like rheumatism, arthritis, inflammation. The Katu, Tikta, Kashaya Rasa of Guggulu possess antagonistic properties to that of Ama and Kapha Dosha which are the chief causative factor of Amavata and the Ushna Virya of Guggulu alleviates vitiated Vata dosha. Due to its Lekhana property Guggulu scraps away from the excessive Jalamsha and Aamatva which has got accumulated in the joints.

Triphala added will reduce the Ushnata and Ugrata of Guggulu. Plumbagin an alkaloid present in Chitraka is a known stimulant of muscle tissue. Deepana and Pachana Dravya like Trikatu help the medicine to get metabolised easily and completely. 
Saindhava Lavana also helps to boost metabolism. Guduchi act as a general tonic, anti-spasmodic, and anti-inflammatory. Bhallathaka has antiinflammatory and analgesic properties. Both the Trivrit and Dantimoola have a laxative property. Swarna Makshika has Yogavahi property which accelerates the properties of others it also has antiinflammatory action. Vidanga is a mild laxative and also alleviates Kapha and Vata Dosha.

Punnarnava Guggulu has main therapeutic action is Shothahara and Vedhanasthapaka which is attributed to the presence of Punnarnava, Eranda Moola and Guggulu being the major content of this formulation. Most of the drug's act as Vatahara, these drugs also act as Agnivardhaka, Vedanasthapaka which is most essential in promoting relief in Amavata.

\section{CONCLUSION}

The Punnarnava Guggulu mentioned in Bhaishajya Rathnavali is Shothahara, Vedhanasthapaka, Vatahara, Agnivardhaka and Amapachaka. The contents of Punnarnava Guggulu directly took part in the Samprapti Vighatan by their individual properties of each drug. It also has anti-inflammatory and analgesic properties. So, it is concluded that Punnarnava Guggulu can be used as an effective medicine for Amavata - Rheumatoid arthritis.

\section{REFERENCES}

1. Dan L Longo, Anthony S Fauci, Dennis L Kasper, Stephen L Hauser, J Larry Jameson, Joseph Loscalzo. Harrison's Principles of Internal Medicine. 18th ed. Volume 2. New York: McGraw Hill Medical; 2012. 2738

2. Smith HR. What is the global prevalence of rheumatoid arthritis (RA) among different age groups and ethnicities? [Internet]. Latest Medical News, Clinical Trials, Guidelines - Today on Medscape. 2021 [cited 2021Nov28]. Available from: https://www.medscape.com/answers/3317155335/what-is-the-global-prevalence-of-rheumatoidarthritis-ra-among-different-age-groups-andethnicities\#: :text=Worldwide $\% 2 \mathrm{C} \% 20$ the $\% 20$ annual $\% 20 \mathrm{in}$ cidence $\% 20$ of,of\%2035\%20and $\% 2050 \% 20$ years.
3. Murthy K R S, English translation on Madhava Nidanam (RogaViniscaya) of Madhavakara. Nidanasthana; Amavatanidanam: Chapter 25, Verse 1,6. Varanasi: Chaukhambha Orientalia,2013:95

4. K C Chunekar, Edited by G S Pandey. Bhavaprakasha Nighantu ofBhavamisra, ChaukhambaBharatiAcademy,2010;406,286,13,195,765,383,386,257,10,5,9,16,2 $1,149,134,50$

5. Ravindra Angadi, English translation on Rasa Tarangini. $1^{\text {st }}$ ed. Chaukhamba Surbharati Prakashan; 2015:496, 342

6. P Sekhar Reddy, A Textbook of Rasashastra. $1^{\text {st }}$ ed. Chaukhambha Orientalia; 2011:432

7. Siddhi Nandan Mishra, Bhaisajya Ratnavali of Kaviraj Govind das Sen. Chaukhamba Surbharati Prakashan; $2009 ; 583$

\section{Source of Support: Nil Conflict of Interest: None Declared}

How to cite this URL: Swathi K S \& Veerakumara K: Review Of Punnarnava Guggulu In The Management Of AmavataRheumatoid Arthritis W.S.R. Bhaishajya Rathnavali. International Ayurvedic Medical Journal \{online\} 2021 \{cited December 2021\} Available from: http://www.iamj.in/posts/images/upload/03113 03117.pdf 